\title{
Working With Wildlife
}

\section{Louisiana resource specialists partner with producers and the public to develop shallow water areas for wildlife.}

\author{
By John Pitre, Wildlife Biologist with USDA, NRCS in Louisiana
}

$\mathrm{T}$ he majority of Louisiana residents are interested in wildlife. Hunting is extremely popular and so is wildlife observation. In terms of migratory waterfowl, we are uniquely positioned at the extreme end of the Mississippi and Central Flyways. Because of this vantage point, in the last few years we have enjoyed the annual visits of more than five million ducks, one million geese, and also countless wading birds, shorebirds, and songbirds. Louisiana usually ranks within the top five states in the number of waterfowl hunters, and is usually at or near the top in duck harvest.

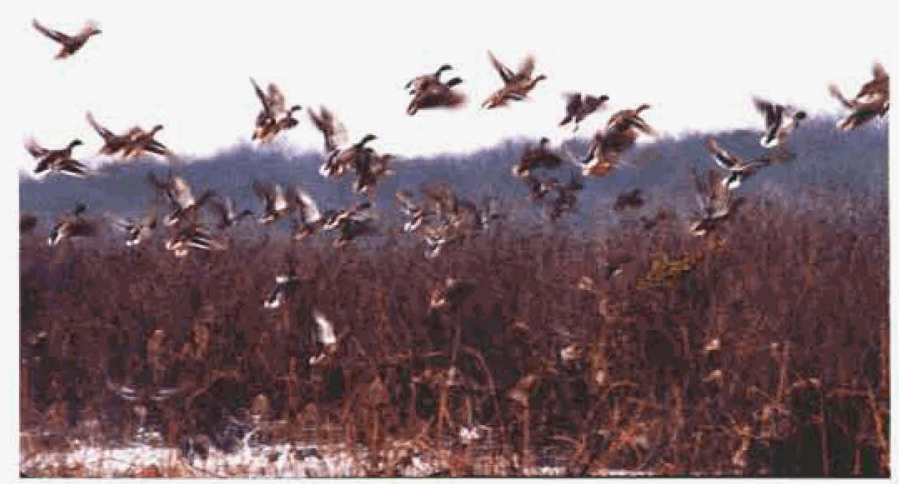

Mallards (Anas platyrhynchos) taking flight from a shallow water area.

Many landowners have realized the importance of incorporating shallow water areas onto their lands. On open lands, such as croplands, pastures, range, and haylands, properly constructing low levees with appropriate water control structures can provide many benefits.

Winter water held on a field protects the soil from erosion, aids in ground water recharge, controls certain weeds, helps stubble decomposition, improves soil moisture, and generally improves soil productivity and water quality.

On grazing lands, shallow water areas may provide an additional source of diverse forage during mid to late summer when the production of other forages has decreased. Shallow water areas benefit numerous game and non-game wildlife species largely due to the moisture regime, biodiversity, and mix of micro-habitats.

In addition to the environmental benefits, on farm shallow water areas can provide personal enjoyment through duck, goose, rail, and snipe hunting, or potential supplemental income through recreational hunting leases and ecotourism.

\section{Management Considerations}

When managing naturally occurring low, wet areas within a pasture, a good rule of thumb is to fence them in or fence them out. That is, make the areas separate management units rather than incorporating them into an adjacent or surrounding pasture.

Livestock use of low, wet areas when they are wet will increase soil compaction and damage to the vegetation. Also, livestock using these areas while they are ponded will result in waste contamination and degraded water quality. This may increase parasite transmission within your herd.

Additionally, water runoff from these areas will tend to carry heavier sediment and nutrient loads to existing water bodies downstream. Thus, creating shallow water areas may provide for better management of areas within an existing pasture that are consistently wetter or hold water longer than the adjacent areas.

\section{Sites For Success}

Creating a successful shallow water area is more than just throwing up a levee and installing a structure. For wildlife use, location is a big factor. Areas should be planned where wildlife use has the greatest potential. Security (from excess hunting, harassment, etc.) should also be considered. Regarding construction, the soils must have water holding capability.

Land clearing, altering drainage, or earth moving activities in wetland areas are regulated activities. Prior to 
this type of work, consult the local NRCS District Conservationist. Levees must be constructed so they will not be compromised during an extreme rainfall event. An adequate watershed is needed to insure proper filling, if rainfall is the only water source.

Drainage of neighboring properties must not be impacted. Also, levees should have slopes of 3 (horizontal) to 1 (vertical) or flatter, should be vegetated, and maintained by mowing. Woody vegetation should not be allowed on the levees as root channels may promote dam failure. The top or crown should be wide enough to provide equipment access. Water control structures must be properly sized and capable of varying water levels.

Financial and technical assistance to construct levees and obtain structures is often available through conservation programs such as CRP, WRP, WHIP, etc. and other conservation organizations such as Ducks Unlimited, Inc.

\section{Maintaining Plant Communities}

The varying of water levels (hydroperiod) is a main factor that determines the type of vegetation produced. Landowners should flood areas by mid November and maintain them at least until around mid March. Timely flooding by rainfall is often an unreliable option. Relifting surface water or pumping well water allows greater control but may be costly.

Areas should be gradually dewatered (over at least a two week period) each spring. The gradual draining crowds invertebrates for feeding wildlife and stimulates diverse plant communities to emerge. Quick drawdowns reduce diversity, typically producing monocultures of vegetation. Quick drawdowns can also stimulate undesirable pioneer plants such as coffeeweed (Sesbania macrocarpa and cocklebur. (Xanthium strumarium).

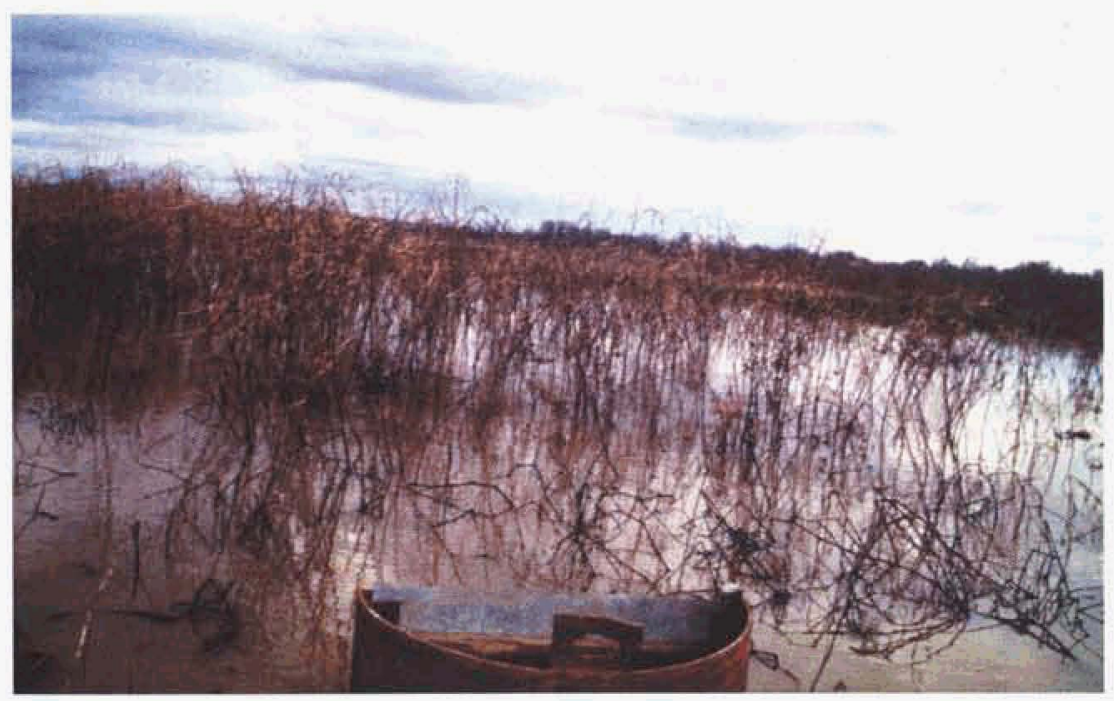

Overlooking a shallow water area from the dike and water control structure.

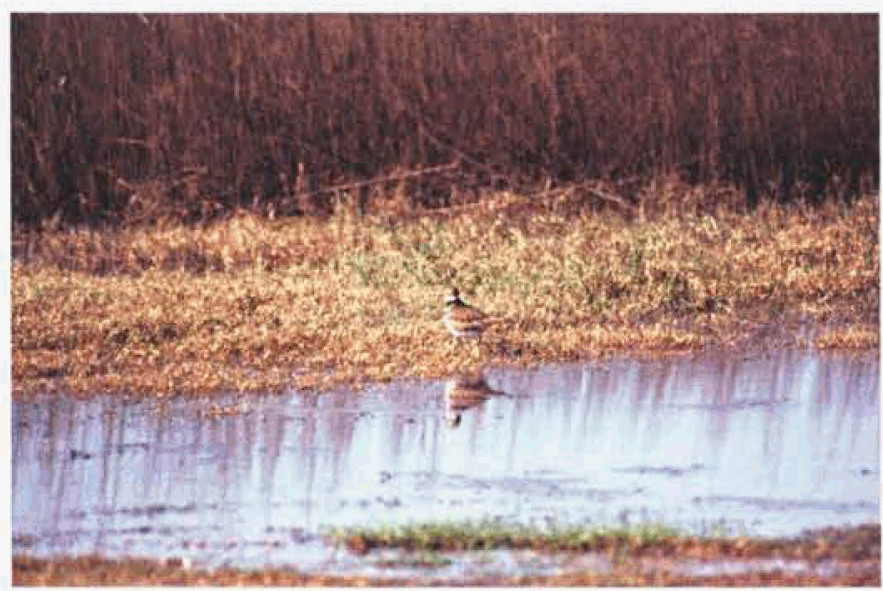

Killdeer (Charadrius vociferus) foraging along a shallow water area.

Variations in the start date of the drawdown will also change the plant community. Although early to midspring drawdowns can yield high seed producers, later drawdowns (May, June, July) provide the water habitat longer and tend to produce desirable annual grasses which also have relatively high forage quality.

Many people often inquire about what to plant for waterfowl. Although food plantings have a place in wildlife habitat enhancement, often the natural vegetation provides more seed and other edible plant parts, more invertebrates (protein sources) without the site preparation, cost of seed, and planting and management labor. In addition, natural vegetation is currently exempt from waterfowl baiting regulations.

Shallow water areas are early successional habitats. In other words, they must be periodically disked, mowed, and/or grazed to keep out advancing woody vegetation and other less desirable perennials. Controlled grazing can be an efficient tool in the manipulation of vegetative succession and a shallow water area can provide a supplemental source of desirable forage, especially in drought conditions.

However, this takes a delicate balancing act. Excessive livestock use can quickly diminish the quality of a shallow water area for wildlife. Small shallow water areas are especially vulnerable to these impacts. Because of the large amount of variables associated with each site, the successful management of a shallow water area is more an art than a science.

For more information regarding shallow water areas and other ways to enhance on farm wildlife habitat, contact your local NRCS Field Office and request the assistance of a Wildlife Biologist. 